\title{
Delivering preventive, predictive and personalised cancer medicine for renal cell carcinoma: the challenge of tumour heterogeneity
}

\author{
Rosalie Fisher ${ }^{1}$, James Larkin ${ }^{1}$ and Charles Swanton ${ }^{2^{*}}$
}

\begin{abstract}
Recent years have seen major advances in the management of metastatic renal cell carcinoma (mRCC). The tyrosine kinase and mammalian target of rapamycin inhibitors have resulted in disease control and improved survival for many patients with mRCC, but they have not led to preventive, predictive or personalised medicine (PPPM). Failure to achieve this rests ultimately with inadequate knowledge of tissue and molecular heterogeneity; discovery of these drugs was based upon identification of pathogenic molecular pathways in RCC, but research into molecular factors which underpin drug response, resistance and selection of therapy for individual patients has lagged well behind clinical trials of drug development. This review will provide an overview of the development of targeted drug therapies for mRCC, will discuss the challenges which currently impede the delivery of PPPM, including identification of biomarkers, drug resistance and molecular heterogeneity, and will propose research methodologies and technologies required to overcome these obstacles.
\end{abstract}

Keywords: Renal cell carcinoma, Heterogeneity, Personalised medicine, Predictive biomarkers

\section{Introduction}

Renal cell carcinoma is a relatively rare cancer in which prognosis is highly individual

Renal cell carcinoma (RCC) is an epithelial neoplasm arising from the parenchyma of the kidney, which accounts for $95 \%$ of renal neoplasms, and 3\% of adult malignancies [1]. RCC is a relatively rare cancer, with an incidence of 60,000 cases in the European Union in 2006, but is associated with a high mortality rate; in the same year, there were 26,000 deaths due to this disease [2].

The prognosis in RCC has traditionally been thought to be influenced by tumour stage, nuclear grade and histologic tumour necrosis [3]. Those patients with disease confined to the kidney and regional lymph nodes are treated with nephrectomy (partial or radical) with curative intent. However, approximately one third of patients have metastases at the time of diagnosis [4], and a similar proportion develop metastatic disease within 5 years

\footnotetext{
${ }^{2}$ Cancer Research UK London Research Institute, Translational Cancer Therapeutics Laboratory, 44 Lincoln's Inn Fields, London WC2A 3LY, UK Full list of author information is available at the end of the article
}

of follow up [5]. Common secondary sites include lymph nodes, lung and bone.

\section{Metastatic RCC is incurable}

Metastatic RCC (mRCC) is incurable, and the aim of therapy for patients with advanced disease is to control the disease burden for as long as possible, thus ameliorating the patient's symptoms and improving quality of life, and prolonging overall survival time. Nephrectomy is still considered standard treatment for those patients who have a good performance status and a limited burden of metastatic disease, based on the results of two randomised studies which found a survival benefit for patients treated with nephrectomy and cytokine therapy, compared with cytokine therapy alone [6]. Historically, patients with mRCC have had extremely limited systemic treatment options and poor 5 year survival rates. Hormone therapy and chemotherapy produce response rates of $10 \%$ or less $[7,8]$. Cytokine therapy, including interferon alfa and high dose interleukin-2, may benefit a small proportion of patients, resulting in response rates of $10-20 \%$, and a modest survival benefit of several months over non-immunotherapy controls $[9,10]$. A 
small number of patients may be cured with high dose interleukin-2 therapy. Despite the recent SELECT trial demonstrating a response rate of $29 \%$ to interleukin-2 [11], there are still no established criteria to select those patients who will benefit from immunotherapy, and these treatments have been associated with substantial toxicity. Thus, an accurate risk-benefit analysis for an individual patient is difficult.

\section{Shifted focus of drug development}

In the last decade, drug development in oncology has shifted its focus from cytotoxic treatments toward biological therapies. The use of 'targeted' therapies is dependent on the identification of biological pathways that selectively confer a growth and/or survival advantage to the cancer cell. There are many examples of drugs which attempt to exploit the underlying biology of the tumour, including trastuzumab, used in Her-2 amplified breast cancer $[12,13]$, the tyrosine kinase inhibitors imatinib for chronic myeloid leukaemia [14], and erlotinib and gefitinib in non-small cell lung cancer $[15,16]$. More recently, breakthroughs have occurred in two refractory tumours with the development of vemurafenib for $B R A F$-mutant melanoma [17] and crizotanib in patients with non-small cell lung tumours with rearrangement of the $A L K$ gene [18]. Arguably, however, renal cell cancer is the solid tumour type that has enjoyed the most success from a targeted approach to therapy, and has the most number of biological agents available for clinical use. Six agents are now approved for mRCC, which target pro-angiogenic and proliferative pathways; the small molecule tyrosine kinase inhibitors sunitinib, sorafenib, and pazopanib, the monoclonal antibody bevacizumab, and the mammalian target of rapamycin (mTOR) inhibitors temsirolimus and everolimus. As a result, the prognosis for patients with mRCC has improved dramatically, and clinicians hope that $\mathrm{mRCC}$ may yet become a 'chronic disease' [19].

\section{RCC is characterised by much heterogeneity}

Despite these advances, $\mathrm{mRCC}$ is a diverse disease with much clinical, pathological and molecular heterogeneity. This argues strongly for an individualised approach to therapy, but a number of obstacles stand in the way of preventive, predictive and personalised medicine for this condition. This review will discuss the pathological and molecular subtypes of RCC, the heterogeneity in clinical course and the role of systemic therapy in this context, and propose mechanisms by which tailored therapy for patients might be achieved.

\section{Pathological and molecular classification of RCC}

The 2004 WHO classification system identifies distinct histological subtypes of RCC [20]; the major subtypes are clear cell, papillary types 1 and 2, chromophobe, and collecting duct cancers. Translocation and medullary tumours and mucinous tubular and spindle cell carcinomas are rare entities. The various subtypes are associated with diverse clinical outcomes, and distinguishing between them may provide a useful indication of prognosis, and guide to appropriate therapy, for an individual patient.

\section{Clear cell RCC}

Clear cell RCC accounts for approximately $75 \%$ of malignant kidney tumours, and $90 \%$ of RCCs that metastasise [21]. So called 'conventional' clear cell RCCs are recognised histologically by clear cell cytoplasm; morphological variants include granular and sarcomatoid carcinomas. Clear cell RCC can be diagnosed from hematoxylin and eosin-stained microscopy, but they are also associated with a typical immunohistochemical pattern with positivity for vimentin, cytokeratin, and CA-IX $[21,22]$. Genetically, clear cell RCC is characterised by loss of DNA in the short arm of chromosome 3 (3p), which has been shown to occur in $79-90 \%$ of cases, as detected by FISH [23]. This region contains the Von Hippel-Lindau $(V H L)$ gene, a tumour suppressor thought primarily responsible in the pathogenesis of hereditary and sporadic clear cell RCC. Inactivation of $V H L$, due to somatic mutation, or hypermethylation, occurs in $100 \%$ of familial RCCs as part of VHL disease, and in up to $80 \%$ of sporadic clear cell tumours [24,25]. The VHL protein (pVHL) regulates hypoxia-inducible factor (HIF) by ubiquitin-mediated destruction $[26,27]$ and in the absence of functional pVHL, HIF activates a number of hypoxiaresponse genes such as vascular endothelial growth factor (VEGF), erythropoietin (Epo), platelet derived growth factor (PDGF), TFG- $\alpha$ and $-\beta$, all of which are associated with tumour angiogenesis and growth [28-30]. HIF gene expression is also increased by activation of mTOR, part of the complex PI3 kinase/Akt pathway, thereby contributing to angiogenesis [31], but this pathway also appears to be critical in promoting in cell growth and survival [32]. A point mutation in $m T O R, \mathrm{R} 2505 \mathrm{P}$, has been identified in renal cell carcinoma, and confers constitutive activation of mTOR signalling [33].

Epigenetic mechanisms, such as DNA methylation and modification of histone proteins, also control gene expression and have an important role in human cancers. Amongst other functions, both of these processes regulate chromatin structure, and are thereby implicated in transcriptional control [34]. Several studies have identified a number of chromatin modifying genes which appear to be closely related to this disease. The histone demethylases $J M J D 1 A$ and $J M J D 2 B$ have been recognised as transcriptional targets of HIF-1, and have 
increased expression in renal cancer cells which lack functional VHL protein [35,36]. A large-scale screen of coding exons of 3544 genes in 101 clear cell RCCs identified activating mutations in SETD2 and JARID1C, both encoding enzymes in histone modification, and mutations in the histone demethylase UTX [37]. However, collectively these mutations are thought to occur in less than $15 \%$ of clear cell RCC, and most recently, truncating mutations in the chromatin remodelling complex gene PBRM1 were found in $41 \%(92 / 227)$ of clear cell RCC cases [38]. Data suggest that PBRM1 is the second major tumour suppressor cancer gene associated with clear cell RCC after $V H L$, regulating pathways associated with chromosomal instability and cellular proliferation. Notably, VHL, PBRM1 and SETD2 genes all map to chromosome $3 \mathrm{p}$ and it is speculated that physical linkage and possibly interaction of these three genes are the key drivers for the $3 p$ loss of heterozygosity commonly seen in clear cell RCC.

\section{Papillary RCC}

Papillary RCC (pRCC) comprises approximately 15\% of malignant kidney tumours. This subtype is further classifed into types 1 and 2, which are morphologically and biologically distinct [39]. Most of these (60-70\%) are type I papillary tumours, which are generally considered to be low grade and are more frequently multifocal [40]. Hereditary papillary renal carcinoma (HRPC) is associated with activating mutations in the $M E T$ gene on chromosome 7 [41]; this oncogene encodes a membrane tyrosine kinase receptor whose ligand is hepatocyte growth factor (HGF). Multiple downstream signalling pathways of the receptor, including P13K, influence cell proliferation, survival and mortality [41,42], and constitutive activation of the network may therefore lead to carcinogenesis. The mutation in MET has also been identified in a small proportion of patients with sporadic type I pRCC [43], but inactivation may occur via epigenetic mechanisms with much higher frequency [44].

Type 2 pRCC, accounting for $30-40 \%$ of papillary tumours, also occurs in hereditary and sporadic forms. However, in contrast to Type 1 pRCCs, these tumours are more likely to be high grade and cytogenetically complex, and are therefore associated with a poor prognosis. Patients with hereditary leiomyomatosis and RCC (HLRCC) have a mutation in the gene encoding the Krebs cycle enzyme fumarate hydratase $(F H)$, and are at risk of developing cutaneous and uterine leiomyomas and an aggressive phenotype of type 2 pRCC [45]. Another familial form of RCC results from germline mutation of succinate dehydrogenase B (SHDB) [46]; $F H$ and $S H D B$ appear to be tumour suppressor genes in which mutations cause increased levels of Krebs cycle enzymes fumarate and succinate respectively. Similar to the pathogenic role of mutations in the isocitrate dehydrogenase metabolic enzymes (IDH1 and $I D H 2$ ) in some gliomas, these mutant metabolic enzymes inhibit prolylhydroxylases in the cell cytosol, which leads to stabilisation of HIF1-alpha and activation [47-49]. Dysregulation of other cell signalling pathways, such as the MYC pathway, may also be relevant in high grade, aggressive type 2 pRCC [50].

\section{Chromophobe RCC}

Five to ten percent of RCCs are chromophobe renal cell carcinomas (ChRCC), which can be difficult to distinguish histologically from renal oncocytoma, a benign neoplasm. However, ChRCC is usually associated with complex loss of multiple chromosomes as detected by FISH [51] and newer gene expression profiling techniques have identified the genes CD82 and S100A1 and $A Q P 6$ which are expressed differentially on ChRCC and oncocytomas respectively [52]. Several studies have reported upregulation of $K I T$, a membrane receptor tyrosine kinase, and have suggested that overexpression may play a pathogenic role in ChRCC [52-54] but its therapeutic relevance is not yet certain.

\section{Rare subtypes}

The remaining RCC subtypes are rare, and less is known of their molecular characteristics. Collecting duct carcinomas, despite being of the same embryological origin as the ureter, do not necessarily share the same molecular abnormalities that characterise urothelial carcinomas. Loss of chromosome $8 p$ in collecting duct tumours has been identified and may be associated with a worse prognosis [55]. The genetic anomalies seen in mucinous tubular and spindle cell carcinoma (MTSCC), a low grade tumour, are heterogenous and require further investigation [56,57]. Xp11 translocation tumours were first included in the WHO classification in 2004, and usually affect children and adolescents $[58,59]$. These tumours have a unique histological appearance and are characterised by a breakpoint at chromosome Xp11 and gene fusions between TFE3 transcription factor and multiple genes [60].

\section{Clinical patterns in mRCC}

$\mathrm{mRCC}$ is associated with significant inter-individual variation in clinical course. Prognosis is often influenced by the histological subtype although this is yet to be fully established. Overall, papillary and chromophobe RCC are thought to portend an improved prognosis compared to clear cell RCC [61], but there are data to suggest these tumours are more resistant to treatment and are associated with poorer survival once they have metastasised [62]. Collecting duct tumours and those with sarcomatoid features behave more aggressively 
than clear cell RCC, with median survivals of 11 months and less than 9 months respectively $[62,63]$.

Furthermore, it is apparent to clinicians who treat $\mathrm{mRCC}$ that there is marked clinical heterogeneity even within a particular subtype. It is well recognised that a subset of patients with $\mathrm{mRCC}$ has an indolent disease course, and many attempts have been made to characterise this group, and to develop methods of predicting the outcome for an individual patient. However, it seems likely that this observation is the result of significant genetic heterogeneity which exists within a histopathological subtype, even when this subtype appears to be dominated by mutations in a single gene. This heterogeneity was clearly demonstrated in the earlier described gene sequencing studies in clear cell RCC [37].

The model most widely used to predict clinical outcomes in mRCC is that defined by the Memorial Sloan Kettering Cancer Center (MSKCC) [9]. A retrospective analysis grouped patients treated in clinical trials of cytokines into favourable, intermediate and poor risk categories on the basis of five factors predictive of short survival; interval from diagnosis to treatment of less than 1 year, Karnofsky performance status less than $80 \%$, elevated serum lactate dehydrogenase (LDH), hypercalcaemia and anaemia. This model was validated in an independent cohort of treatment-naive patients, and prior radiotherapy and sites of metastasis were also identified as negative prognostic factors [64]. Several models have been described for use in patients treated with tyrosine kinase inhibitors. Patient outcomes from the phase III, landmark trial of sunitinib versus interferon were analysed and 11 pre-treatment factors were used to develop a nomogram which predicts the probability of 12 month progression free survival [65]. This tool is clearly restricted to those treated with sunitinib and may not be generalisable to patients outside a clinical trial; it also requires independent validation. Heng et al. reported that components of the MSKCC model are valid in patients treated with VEGF-targeted therapy (anaemia, hypercalcaemia, Karnofsky performance status and time from diagnosis to treatment of less than 1 year) and added platelet and neutrophil counts as independent adverse prognostic factors [66]. This analysis was based on a heterogeneous patient population and the authors argue that is widely applicable to patients treated in the kinase inhibitor era. However, all of the models described above are limited on the basis of retrospective analyses and their utilisation of pre-treatment risk factors only.

Prognostic models such as these have been used to select those patients with an improved risk profile who may benefit from alternatives to systemic therapy. For example, it is common clinical practice to observe patients with indolent, asymptomatic metastatic disease and a recent retrospective review confirmed that this strategy may be reasonable for some patients, although the selection criteria are yet to be defined, and prospective confirmatory data are required [67]. Surgical resection of metastatic disease is another therapeutic option, particularly historically when there was a lack of effective systemic therapy. Anecdotal reports of metastasectomy resulting in long term survival date back to 1939 [68], and 5 year survival rates associated with complete resection of metastases ranged between 35 and $60 \%$ [69]. Recently, Alt et al. reported on the survival of 887 patients treated with nephrectomy, who subsequently developed metastases [70]. Of these, 124 patients underwent surgical resection of all metastases and had a median 5-year cancer specific survival rate of $32.5 \%$, compared to $12.4 \%$ for those patients who did not undergo metastasectomy. Outcomes were further improved in patients with lung-only metastases, who had a 5 -year cancer specific survival rate of $73.6 \%$ if completely resected. There are also recent reports of patients achieving durable complete responses through a combination of systemic anti-angiogenic therapy and subsequent metastasectomy [71,72]. Surgical series of patients with mRCC are small with a heavy selection bias; nevertheless, when complete histological resection is achieved, metastasectomy for some individuals anecdotally improves survival, and may be curative in a minority. Surgery to remove metastases may also provide effective symptom palliation, and in the setting of oligometastastic disease, it might obviate the need for systemic treatment, which is usually associated with side effects. Again, there is no robust evidence to guide selection of patients for surgery, and the optimal timing of surgery and integration of treatment modalities in the targeted therapy era are unknown.

\section{Systemic therapy for mRCC and personalised medicine} Systemic treatments used in $\mathrm{mRCC}$

As discussed previously, cytotoxic and hormonal therapies have had a limited role in the treatment of mRCC, and until 2005, immunotherapy was the treatment of choice, despite providing clinical benefit for only a minority of patients. Since 2005, a number of new agents have been developed and approved for use in this disease with substantial improvements in patient outcomes. Broadly, current treatments can be classified as antiVEGF agents, mTOR inhibitors, immunotherapy and cytotoxics.

Sunitinib is an oral inhibitor of multiple receptor tyrosine kinases (RTKs), including VEGFR, PDGFR, FLT-3 and c-KIT $[73,74]$. The phase III trial of sunitinib versus interferon, in patients with untreated, clear cell mRCC, 
established sunitinib as the standard of care for first-line treatment, with a median progression free survival time of 11 months for patients treated with sunitinib, compared with 5 months for those treated with interferon. A statistically significant difference in overall survival was found when patients who crossed over from interferon to sunitinib (approximately $1 / 3$ of those randomised) were excluded from the analysis [75]. These results were confirmed in a broader $\mathrm{mRCC}$ population in an expanded access trial [76]. Sorafenib is also an orally administered multi-targeted tyrosine kinase inhibitor (TKI), inhibiting VEGFR-2 and -3, PDGFR, FLT3, cKIT, RET, BRAF and CRAF [77], and also resulted in an approximate doubling of median progression free survival times compared with placebo in patients who had progressed after first line cytokine therapy; median PFS for sorafenib was 5.5 months compared with 2.8 months in the placebo group [78]. Again, overall survival results were confounded by patient crossover from placebo to sorafenib. A third drug in this class is pazopanib, a second generation TKI targeting VEGFR-1, -2 and -3, PDGFR and cKIT; in particular, preclinical studies established it as very potent inhibitor of VEGFR-2 [79]. Based on a randomised phase III trial, pazopanib appears to have similar efficacy to sunitinib in the first line treatment of $\mathrm{mRCC}$, with a median PFS of 9.2 months, compared to 4.2 months for placebo-treated patients [80], and an overall survival difference of 2.4 months in favour of pazopanib [81]. Results of a phase III trial directly comparing sunitinib and pazopanib are awaited.

The mammalian target of rapamycin (mTOR) is a non-receptor tyrosine kinase in the PI3K-Akt pathway. Activation of mTOR has multiple downstream consequences including upregulated HIF expression [31] and effects on intracellular signalling pathways involved in cell growth and proliferation $[82,83]$. The mTOR inhibitors, temsirolimus and everolimus, bind to FK506-binding protein (FKBP) and this protein-drug complex inhibits the kinase activity of the mTOR complex 1 (mTORC1) [84]. Disruption of mTOR signalling results in reduced translation of cell cycle regulatory proteins, such as D-type cyclins, c-myc and p $27^{\text {kip-1 }}$ [85], and suppressed angiogenesis [86,87] (Figure 1). Temsirolimus, an intravenously administered mTOR inhibitor, significantly prolonged median overall survival in patients with untreated, poor-risk $\mathrm{mRCC}$, when compared with interferon, or the combination of inter-feron and temsirolimus in a phase III trial (10.9 months for temsirolimus, 7.3 months for interferon, and 8.4 months for the combination) [88]. Everolimus is an oral mTOR inhibitor and was established as the standard of care for second line treatment after failure of VEGF-directed TKI therapy following a phase III trial in which everolimus treatment resulted in significantly prolonged progression free survival compared to placebo [89].

Bevacizumab is a humanised monoclonal antibody against VEGF. A randomised phase II trial established that it had clinically meaningful activity in patients with mRCC [90] and two independent phase III trials combined bevacizumab with interferon- $\alpha$ in an attempt to improve its efficacy $[91,92]$. Both studies reported improved progression free survival with combination treatment compared to interferon alone, and justify the use of this combination in first line therapy of metastatic RCC in intermediate- and good-risk patients. However, neither trial observed a difference in overall survival from the addition of bevacizumab, possibly because the majority of patients in both studies received subsequent, second-line therapy which included VEGFtargeted treatments.

Immunotherapy and cytotoxic agents are no longer considered standard therapies in mRCC. However, the regimen of capecitabine and gemcitabine chemotherapy has demonstrated activity in MRCC [93-96], and there is a recent report of two patients with prolonged remissions after treatment with this combination, and in the setting of failed targeted therapy [97]. There are also encouraging early results from a novel immunotherapy, anti-PD-1 (MDX-1106), which acts to enhance antitumour T-cell response [98]. PD-1 is a so called 'immune checkpoint molecule' found on activated T, B and myeloid cells, whose ligand is $\mathrm{B} 7-\mathrm{H} 1-$ the interaction between PD-1 and B7-H1 down-regulates $\mathrm{T}$ cell activation [99] (Figure 2). B7-H1 is constitutively expressed in many human carcinomas but not in normal tissues [100] and expression of B7-H1 in nephrectomy specimens has been associated with a worse prognosis in patients with RCC [101].

It is important to note that patients with non-clear cell $\mathrm{mRCC}$ have been largely excluded from the pivotal clinical trials of the newer agents, apart from the randomised study of temsirolimus [88] and the expanded access trials of sunitinib and sorafenib [76,102]. The largest retrospective series of patients with papillary or chromophobe mRCC treated with sunitinib or sorafenib demonstrated that there was clinically meaningful activity of these agents for some individuals, but that this was lower than that observed in patients with clear cell mRCC [103]. Subset analyses of the phase III temsirolimus trials suggest greater benefit of temsirolimus (relative to interferon) in patients with non-clear cell mRCC $[104,105]$. A prospective phase II trial examining the response rate to sunitinib in papillary $\mathrm{mRCC}$ found it was significantly lower in these patients compared with clear cell patients [106], but further data on the efficacy of anti-VEGF and mTOR treatments in non-clear cell histologies from phase III trials are awaited. 


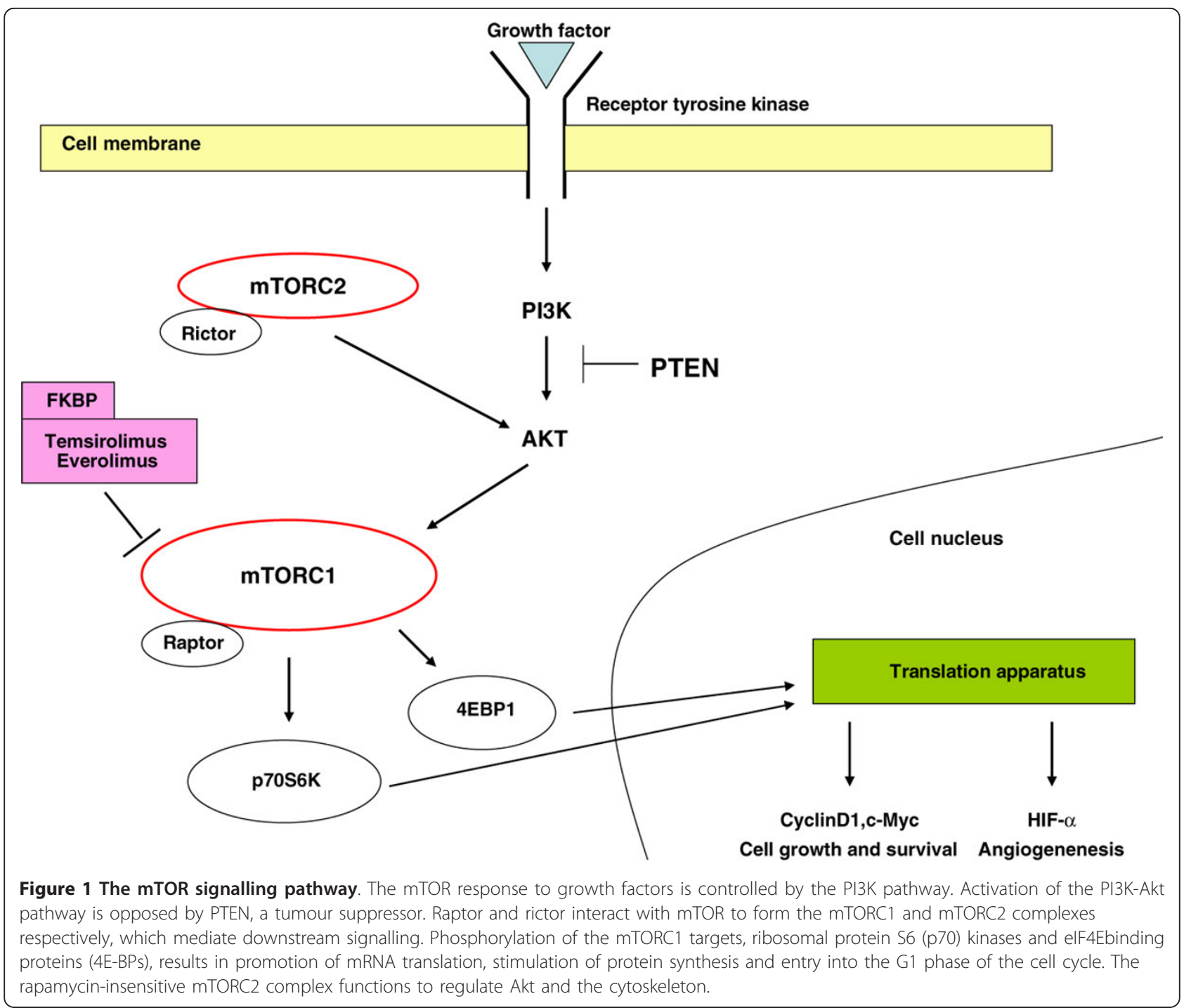

Personalised systemic therapy in mRCC

Despite clear advances in the treatment of $\mathrm{mRCC}$ with the development of the above-mentioned drugs, molecularly directed personalised medicine approaches for this condition have not been achieved. There are no established criteria by which to select one treatment over another for an individual patient, apart from clinical factors such as the desire to have oral rather than intravenous therapy, and patient co-morbidities and performance status. Equally important is the lack of predictors of response or resistance to therapy. This is in obvious contrast to other tumour types, such as lung, breast, and colorectal cancers, and now melanoma, in which biomarkers are used routinely to predict response to treatment. Biomarkers can be defined as molecular, cellular or functional measurable parameters indicative of important clinical events such as cancer onset, recurrence, progression or death [107]. The fact that none have been identified for use in mRCC may be because agents such as sunitinib act on non-tumour components such as the endothelium, rather than on the tumour cell itself [108], but may also reflect a lack of systematic tissue collection in the drug development trials for mRCC to date. None of the phase III trials of the drugs currently in use for mRCC included mandatory tissue collection in their protocols, and no prospective translational endpoints were included in these studies. Another issue unique to RCC and which impedes the identification of biomarkers is its marked tissue heterogeneity. Biomarker discovery trials to date have been based on the assumption that a single biopsy reflects the somatic mutation landscape of the tumour, but variation of growth pattern and cytological features are frequently 


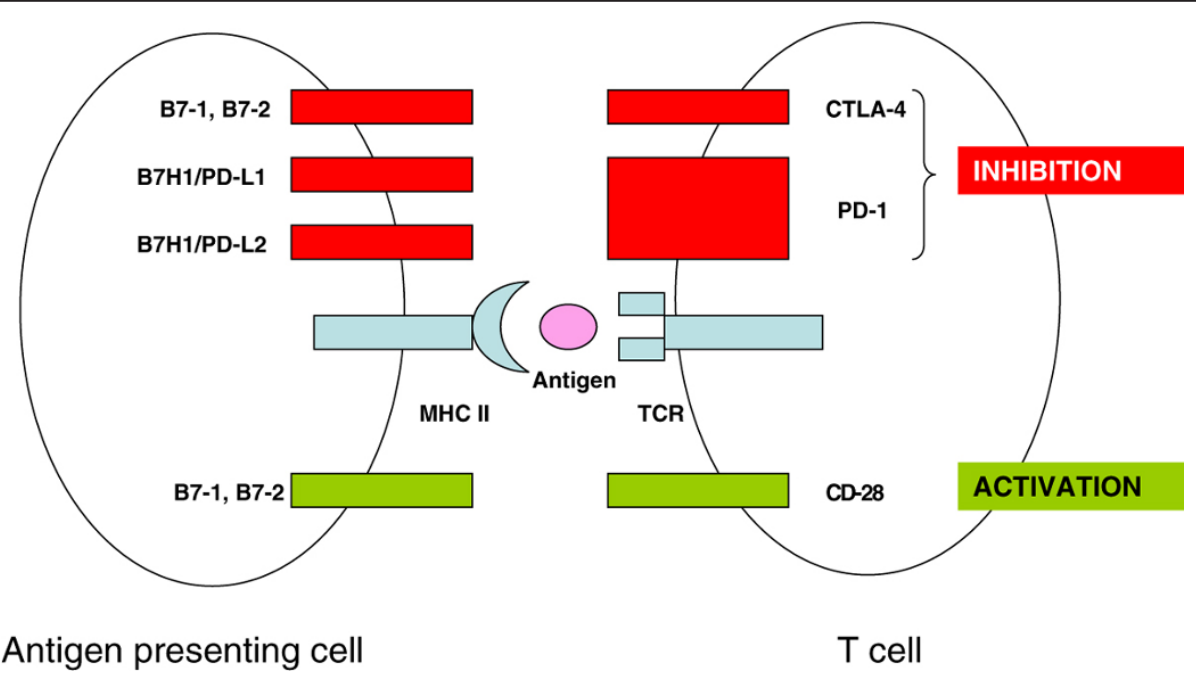

Figure 2 Model of immune checkpoint molecules and T cell function. Inhibitory T cell co-receptors such as CTLA-4 and PD-1 cause T cell anergy and apoptosis, impeding anti-tumour immunity. Abbreviations: B7H1/PD-L1 and B7H1/PD-L2 ligands for PD-1; PD-1 programmed death-1; MHC II major histocompatability complex class II.

identified within the same lesion and sampling of multiple areas within the same lesion would be required to assess the extent of molecular heterogeneity [109].

\section{Candidate biomarkers in RCC}

Research into potential biomarkers for $\mathrm{mRCC}$ has focussed on the clear cell subtype, because it is the dominant histological type, but also because the molecular pathogenesis has been well defined. In almost all cases of clear cell RCC there is loss of function of the $V H L$ tumour suppressor gene, yet $V H L$ gene status has not been reliably demonstrated to have prognostic or predictive value. Choueiri et al. demonstrated a differential response rate in 123 patients with clear cell mRCC treated with anti-VEGF therapy (sunitinib, sorafenib, axitinib or bevacizumab) according to $V H L$ status [110]. Those patients with inactivated $V H L$, defined by mutation or methylation, had a similar response rate to those with wild-type VHL (41\%, compared to $31 \%$ ). Those with a loss of function mutation in VHL had a higher response rate of $52 \%$, but this did not translate into improved progression-free or overall survival. Obvious limitations of this analysis are its retrospective nature and differences in the treatments given, and the overall survival data were immature at the time of publication. The improved response rates were not confirmed by two further studies; in 13 patients treated with axitinib, and in 78 patients treated with pazopanib, there was no relationship between VHL gene status and response $[111,112]$.

HIF plays a critical role in the VHL pathway as a transcription factor for angiogenic genes in the absence of functional VHL protein. It consists of two alpha subunits (HIF-1 alpha and HIF-2 alpha) and one stably expressed beta subunit. The two alpha subunits are thought to have similar but not fully redundant functions, and it has been suggested that HIF-2-alpha may be more important than HIF-1-alpha in angiogenesis [113]. Gordan et al. distinguished two types of $V H L-$ deficient clear cell RCC; those that express HIF-1-alpha and those that do not [114], but the clinical relevance of this remains to be determined and there have been conflicting results from studies examining HIF-1-alpha expression as a prognostic biomarker [115-118]. In a retrospective study of archival tissue from 43 patients with clear cell mRCC treated with sunitinib, high pretreatment levels of HIF-1-alpha or HIF-2-alpha predicted sensitivity to treatment but these results require prospective validation [119].

Two of the many HIF-responsive genes, VEGF and $C A I X$, have also been explored as potential biomarkers in mRCC. The VEGF family is a key mediator of angiogenesis and comprises multiple VEGF ligands, and three cognate tyrosine kinase receptors. In the phase III trial comparing sorafenib with placebo (TARGET trial), baseline plasma levels of VEGF were available for 712 patients. Retrospective exploratory analysis revealed that high baseline VEGF levels were associated with reduced overall survival, but there was no relationship demonstrated between changes in VEGF and soluble VEGF receptor 2 (sVEGFR-2) levels during treatment and patient outcomes [120]. Pre-treatment serum VEGF levels were also shown to be prognostic in a study of 302 patients with mRCC enrolled in cytokine clinical trials [121], but were not predictive of response to bevacizumab in patients treated in the AVOREN study [122]. However, Rini et al. demonstrated that baseline 
plasma soluble VEGF receptor 3 (sVEGFR-3) and VEGF-C levels correlated with improved response rates and longer progression-free survival times in patients treated with suni-tinib [123]. Two small phase II studies of sunitinib and pazopanib in $\mathrm{mRCC}$ also suggest a potential role for VEGF and the soluble forms of the VEGF receptor as predictive biomarkers; the first study found that significantly larger reductions in VEGF, sVEGFR-2 and sVEGFR-3 levels occurred in patients exhibiting an objective response to sunitinib, and in the second, decreases in sVEGFR-2 were significantly correlated with tumour response $[112,124]$. Given these conflicting results, the clinical utility of the VEGF family as predictive biomarkers is uncertain.

Similarly, studies evaluating the potential of CAIX as a biomarker in $\mathrm{mRCC}$ are hypothesis-generating only. $C A I X$ is a surface transmembrane enzyme that is highly expressed in advanced RCC but not in normal kidney tissue [125]. In several studies, tumours with low CAIX staining by immunohistochemistry were associated with worse clinical outcomes [125,126], but the largest series which examined 730 clear cell RCC specimens, reported by Leibovich et al., did not validate these findings [127]. There is limited evidence from two small studies to suggest that high tumour CAIX staining may be a useful predictor of benefit from interleukin-2 immunotherapy $[128,129]$ and is currently under evaluation by the Cytokine Working Group in the SELECT trial. CAIX does not appear to be predictive of response to sunitinib, sorafenib or temsirolimus $[120,130]$.

Neutrophil gelatinase-associated lipocalin (NGAL) has shown promise as predictive biomarker for $\mathrm{mRCC}$ patients treated with sunitinib. NGAL is a protein that is present in low levels in some human tissues, but is induced by epithelial damage in the kidney, colon, liver and lung [131]. It is a marker of acute and chronic kidney injury $[132,133]$ and is elevated in a number of cancers, when it is usually associated with a poor prognosis [134]. It may be complexed with matrix metalloproteinase-9, which plays a role in invasion and metastasis. Porta et al. compared the predictive value of the Motzer scoring system with baseline serum concentrations of VEGF and NGAL in a cohort of 85 patients treated with sunitinib [135]. Both biomarkers correlated significantly with progression-free survival, whereas MSKCC score did not. Patients classified as having high levels of VEGF or NGAL (according to a threshold defined by the manufacturer of the ELISAs used) had a relative risk of progressing of 2.14 and 1.86 respectively, compared to patients with normal levels.

Components of the mTOR pathway have been evaluated as potential biomarkers in mRCC. Constitutive activation of the mTOR kinase via the PI3K and AKT signalling network results in activation of substrates, such as the ribosomal subunit S6 kinase (S6K) and eukaryotic initation factor $4 \mathrm{E}$, which are critical for synthesis of proteins involved in cellular growth and survival. Activation of the AKT pathway can occur through homozygous loss of the PTEN tumour suppressor gene, but there is no definite prognostic significance for PTEN loss in mRCC [136,137], and there does not appear to be a correlation between tumour PTEN expression and benefit from temsirolimus [138]. There are also conflicting results for phosphorylated AKT (pAKT) as a prognostic biomarker [136,137]. However, Cho et al. found a positive association between phosphorylated S6 (pS6) expression and a trend towards positive expression of pAKT with response to temsirolimus [130]. Elevated lactate dehydrogenase (LDH) also appears to predict for an increase in overall survival with temsirolimus in poor-risk patients treated with temsirolimus [139]. LDH is a serum enzyme, which is regulated by the PI3K-Akt-mTOR pathway and tumour hypoxia. It is elevated in many cancers, and has prognostic significance in RCC. In this study of 404 patients treated with temsirolimus or interferon, there was a significant increase in patients with an elevated LDH treated with temsirolimus $(n=140)$, but in patients with a normal LDH $(n=264)$ there was no survival difference between temsirolimus and interferon treatments.

There is an emerging role for genetic biomarkers in prognostication in $\mathrm{mRCC}$. Traditional cytogenetic karyotyping studies have demonstrated loss of 3p, 4p, 9p and $14 \mathrm{q}$ as possible prognostic genetic biomarkers in $\mathrm{mRCC}$ [140], but modern techniques such as gene expression profiling and single nucleotide polymorphism (SNP) genotyping seem more likely to be able to pinpoint specific carcinogenetic events or predict outcomes from treatment. Two studies analysing gene expression profiles in clear cell RCC have identified panels of candidate genes that appear to correlate strongly with survival and recurrence-free interval $[141,142]$. The first study of 177 clear cell tumours classified tumours into two subsets, defined by a set of gene features, each with distinct prognoses and biological behaviours. The second study is the largest genomic series to date, and analysed 931 archival specimens from the Cleveland Clinic by RT-PCR for expression of 727 genes (including 5 reference genes). Sixteen genes were identified as strongly associated with recurrence-free interval, and interestingly, among these 16 genes, increased expression of angiogenesis and immune-related genes correlated with a lower risk of recurrence, whereas a higher risk of recurrence was demonstrated with expression of genes associated with epithelial to mesenchymal transition. It is hoped that validation of results achieved in 
studies such as these may lead to the development of multiple gene algorithisms, which could be used to predict recurrence of RCC.

There is preliminary evidence that SNP genotyping could be used to recognise SNP variants that influence prognosis in patients with mRCC. In a study of 80 patients with mRCC, analysis of 21 NSPs within 13 cytokine genes revealed that heterozygosity for the IL-4 genotype $-589 \mathrm{C}-33 \mathrm{C}$ resulted in a five-fold reduction in median overall survival, compared with homozygotes for IL-4 haplotype -589C-33C [143]. Another study identified three SNP polymorphisms in the VEGF gene associated with survival [144], and in pazopanib-treated patients, SNPs in genes related to angiogenesis, and pazopanib mechanism of action and metabolism have been associated with overall survival [145].

Finally, there are clinical and functional parameters that may prove to be useful tools in predicting patient outcomes and response to targeted treatments in $\mathrm{mRCC}$. Although retrospective, there is rather compelling data demonstrating a consistent relationship between hypertension induced by anti-VEGF treatments, and improved clinical outcomes. In a retrospective pooled analysis of four studies of sunitinib in mRCC, patients who achieved a maximum systolic blood pressure of $140 \mathrm{mmHg}$ or higher had marked improvements in objective response rates, progression-free and overall survival, and a weaker association was observed in sunitinib-induced hypertension when defined by a maximum diastolic blood pressure [146]. Similar results have been reported in patients treated with axitinib and bevacizumab $[147,148]$. There are obvious limitations to these retrospective analyses, and a prospective study of firstline axitinib (a newer multi-targeted TKI) will evaluate the strategy of dose escalation of axitinib in the absence of treatment-related hypertension or toxicity, on the basis of a study demonstrating that hypertension and axitinib drug levels are independently associated with clinical outcome [149]. Furthermore, SNPs of VEGF and VEGFR that predict the occurrence of hypertension in patients receiving sunitinib have been proposed [150].

Early, small studies of treatment-induced radiographic phenomena have shown promise but require much larger, prospective investigation. For example, changes in tumour blood flow as measured by arterial spin labelling magnetic resonance imaging (MRI) after 1 month of treatment with PTK787, a small molecule VEGF inhibitor, correlated with objective response at 4 months of therapy [151]. An alternative functional MRI technique found that the baseline volume transfer constant of the contrast agent (Ktrans), indicating higher vascular permeability, correlated with subsequent progression free survival on sorafenib, but changes in Ktrans during treatment did not predict for clinical outcome [152].
In summary, there are no biomarkers that have been approved for use in mRCC. Although the data described above provides many promising leads, it is limited by retrospective analyses, and inconsistencies in researchbased assays, which in turn depend on the method of sample collection, processing and interpretation [131].

\section{Drug resistance and molecular heterogeneity also impede} PPPM

Other challenges faced by clinicians and scientists in the pursuit of personalised medicine for $\mathrm{mRCC}$ include resistance to therapy and intra-tumoural heterogeneity. Between a third and two-thirds of patients with $\mathrm{mRCC}$ have tumours refractory to anti-VEGF and mTOR inhibitor treatment from the outset, and all patients inevitably acquire resistance to therapy [153]. There is an increasing understanding of mechanisms of resistance, which may include vascular resistance through activation of alternative pro-angiogenic pathways [154], and hypoxia resistance [153]. Resistance to mTOR inhibition is less well understood but preclinical models suggest that negative feedback loops and parallel signalling pathways such as the Ras-mitogen-activated protein kinase (MAPK) pathway play an important role [153]. Again, routine tissue collection at important clinical timepoints (such as pre-treatment, and at the time of progressive disease) is likely to add to the mounting body of evidence delineating resistance pathways. The European Union multi-disciplinary Personalised RNA Interference to Enhance the Delivery of Individualised Cytotoxic and Targeted therapeutics (PREDICT) consortium has identified four key areas of research, and obstacles to individualised therapy in mRCC-these are the identification of predictive and surrogate biomarkers, determination of the mechanisms of resistance and response to VEGF-targeted therapy, and the identification of new targets [155]. It is hoped that these endpoints will be addressed through the analysis of tumour tissue collected in pre-operative biopsy studies in mRCC, using novel methods of personalise tumourderived small hairpin RNA and high-throughput small interfering RNA screens.

\section{Intratumour heterogeneity: a challenge to personalised medicine and biomarker discovery}

It is clear that the histological subtypes of RCC differ in their molecular profiles, and systematic screens of genes involved in RCC have revealed substantial genetic heterogeneity even within the clear cell subtype, previously thought to be dominated by a mutation in a single gene, $V H L[37,156,157]$. Furthermore, it is emerging that intratumour heterogeneity exists. It is this which presents the biggest challenge to biomarker discovery in RCC, and genetic instability may independently contribute to multiple drug resistance $[158,159]$. 
Moch et al. analysed 53 clear cell and papillary RCCs by fluorescence in situ hybridisation (FISH) for $V H L$ deletions, and confirmed that $V H L$ deletions were present in $69 \%$ of clear cell RCCs, consistent with previous studies. However, within individual clear cell tumours, subpopulations of cells with and without $V H L$ deletion existed, and $V H L$-depleted subpopula-tions had different chromosome 3 counts [157]. The situation has become much more complex since this study was published, with the discovery of multiple genes implicated in RCC, and there are intensive efforts underway to define the clonal architecture of RCC tumours. This will require multiple biopsies of individual primary and secondary tumours; to date, there are no published data using this approach in mRCC but it is a method being utilised in the PREDICT consortium's pre-operative trials of mTOR and kinase inhibitors [155].

\section{Conclusions and outlook}

There have been significant developments in the treatment of $\mathrm{mRCC}$ in recent years, but preventive, predictive and personalised medicine for this condition remains elusive. Failure to provide such tailored treatment for patients clearly has profound clinical and social implications for individuals but also impacts heavily on health economies. Personalised medicine will not be achieved unless there is an improved understanding of the mechanisms which underpin response and resistance to therapy, and biological markers of these processes. A paradigm shift is required, in which clinicians select treatments based on molecular, rather than anatomical or histopathological criteria. After all, knowledge of molecular pathways in RCC has led to the development of the therapeutic agents which have already resulted in vast improvements in clinical outcomes for patients. However, enhanced understanding of comprehensive molecular networks, and intra- and inter-tumour heterogeneity is the key to further improvements in the treatment of mRCC. Clinical trial design will need to adapt in order to achieve this goal; in particular, preoperative studies in this field offer a unique opportunity for researching the biology of this complex malignancy.

Finally, this review has focussed on treatment of metastatic RCC, and whilst it is clearly desirable to improve survival and quality of life for those patients with advanced disease, it is also true that overall improvements in outcomes in this condition, as in other tumour types, depends on superior treatment of early disease and prevention of metastastic spread. Currently no standard adjuvant therapy exists for patients after nephrectomy for RCC, but there is no doubt that the progress made in the field of metastatic RCC will translate into more rational management of localised disease with appropriate integration of surgical and medical therapy.

\section{Author details}

'Department of Medicine, Royal Marsden Hospital, London, UK. ${ }^{2}$ Cancer Research UK London Research Institute, Translational Cancer Therapeutics Laboratory, 44 Lincoln's Inn Fields, London WC2A 3LY, UK.

Received: 29 September 2011 Accepted: 2 December 2011

Published: 22 December 2011

\section{References}

1. Jemal A, Siegel R, Xu J, Ward E: Cancer statistics. CA Cancer J Clin 2010, 60:277-300.

2. Ferlay J, Autier $\mathrm{P}$, Boniol $\mathrm{M}$, Heanue $\mathrm{M}$, Colombet $\mathrm{M}$, Boyle P: Estimates of the cancer incidence and mortality in Europe in 2006. Ann Oncol 2007, 18:581-92.

3. Frank I, Blute ML, Cheville JC, Lohse CM, Weaver AL, Leibovich BC, et al: A multifactorial postoperative surveillance model for patients with surgically treated clear cell renal cell carcinoma. J Urol 2003, 170:2225-32.

4. Motzer RJ, Bander NH, Nanus DM: Renal-cell carcinoma. N Engl J Med 1996, 335:865-75.

5. Leibovich BC, Blute ML, Cheville JC, Lohse CM, Frank I, Kwon ED, et al: Prediction of progression after radical nephrectomy for patients with clear cell renal cell carcinoma: a stratification tool for prospective clinical trials. Cancer 2003, 97:1663-71.

6. Flanigan RC, Mickisch G, Sylvester R, Tangen C, Van Poppel H, Crawford ED: Cytoreductive nephrectomy in patients with metastatic renal cancer: a combined analysis. J Urol 2004, 171:1071-6.

7. Harris DT: Hormonal therapy and chemotherapy of renal-cell carcinoma. Semin Oncol 1983, 10:422-30.

8. Yagoda A, Bander NH: Failure of cytotoxic chemotherapy, 1983-1988, and the emerging role of monoclonal antibodies for renal cancer. Urol Int 1989, 44:338-45.

9. Motzer RJ, Bacik J, Murphy BA, Russo P, Mazumdar M: Interferon-alfa as a comparative treatment for clinical trials of new therapies against advanced renal cell carcinoma. J Clin Oncol 2002, 20:289-96.

10. Coppin C, Porzsolt F, Awa A, Kumpf J, Coldman A, Wilt T: Immunotherapy for advanced renal cell cancer. Cochrane Database Syst Rev 2005, 25 : CD001425.

11. McDermott DF, Ghebremichael M, Signoretti S, Margolin KA, Clark J, Sosman JA, et al: The high-dose aldesleukin 'SELECT' trial in patients with metastatic renal cell carcinoma. J Clin Oncol 2010, 28, Abstr 4514.

12. Slamon DJ, Leyland-Jones B, Shak S, Fuchs H, Paton V, Bajamonde A, et al: Use of chemotherapy plus a monoclonal antibody against HER2 for metastatic breast cancer that overexpresses HER2. N Engl J Med 2001, 344:783-92.

13. Piccart-Gebhart MJ, Procter M, Leyland-Jones B, Goldhirsch A, Untch M, Smith I, et al: Trastuzumab after adjuvant chemotherapy in HER2-positive breast cancer. N Engl J Med 2005, 353:1659-72.

14. Druker BJ, Sawyers CL, Kantarjian H, Resta DJ, Reese SF, Ford JM, et al: Activity of a specific inhibitor of the BCR-ABL tyrosine kinase in the blast crisis of chronic myeloid leukemia and acute lymphoblastic leukemia with the Philadelphia chromosome. N Engl J Med 2001, 344:1038-42.

15. Shepherd FA, Rodrigues Pereira J, Ciuleanu T, Tan EH, Hirsh V, Thongprasert S, et al: Erlotinib in previously treated non-small-cell lung cancer. N Engl J Med 2005, 353:123-32.

16. Maemondo M, Inoue A, Kobayashi K, Sugawara S, Oizumi S, Isobe H, et al: Gefitinib or chemotherapy for non-small-cell lung cancer with mutated EGFR. N Engl J Med 2010, 362:2380-8.

17. Chapman PB, Hauschild A, Robert C, Haanen JB, Ascierto P, Larkin J, et al: Improved Survival with Vemurafenib in Melanoma with BRAF V600E Mutation. N Engl J Med 2011, 364:2507-16.

18. Kwak EL, Bang YJ, Camidge DR, Shaw AT, Solomon B, Maki RG, et al: Anaplastic lymphoma kinase inhibition in non-small-cell lung cancer. $N$ Engl J Med 2010, 363:1693-703.

19. Larkin J, Gore M: Is advanced renal cell carcinoma becoming a chronic disease? Lancet 2010, 376:574-5.

20. Sauter G, Eble JN, Epstein JI, Sesterhenn IA: World Health Organisation classification of tumours: pathology and genetics of tumours of the urinary system and male genital organs. Lyon: IARC 2004.

21. Reuter VE, Tickoo SK: Differential diagnosis of renal tumours with clear cell histology. Pathology 2010, 42:374-83. 
22. Cheng L, Williamson SR, Zhang S, Maclennan GT, Montironi R, LopezBeltran A: Understanding the molecular genetics of renal cell neoplasia: implications for diagnosis, prognosis and therapy. Expert Rev Anticancer Ther 2010, 10:843-64.

23. Siebert $R$, Jacobi $C$, Matthiesen $P$, Zuhlke-Jenisch R, Potratz C, Zhang $Y$, et al: Detection of deletions in the short arm of chromosome 3 in uncultured renal cell carcinomas by interphase cytogenetics. J Urol 1998, 160:534-9.

24. Gnarra JR, Tory K, Weng Y, Schmidt L, Wei MH, Li H, et al: Mutations of the VHL tumour suppressor gene in renal carcinoma. Nat Genet 1994, 7:85-90.

25. Kim WY, Kaelin WG: Role of VHL gene mutation in human cancer. J Clin Oncol 2004, 22:4991-5004.

26. Kamura T, Sato S, Iwai K, Czyzyk-Krzeska M, Conaway RC, Conaway JW Activation of HIF1alpha ubiquitination by a reconstituted von HippelLindau (VHL) tumor suppressor complex. Proc Natl Acad Sci USA 2000 97:10430-5.

27. Ohh M, Park CW, Ivan M, Hoffman MA, Kim TY, Huang LE, et al: Ubiquitination of hypoxia-inducible factor requires direct binding to the beta-domain of the von Hippel-Lindau protein. Nat Cell Biol 2000, 2:423-7.

28. Kaelin WG Jr: The von Hippel-Lindau tumor suppressor protein and clear cell renal carcinoma. Clin Cancer Res 2007, 13:680s-4s.

29. Krause DS, Van Etten RA: Tyrosine kinases as targets for cancer therapy. $N$ Engl J Med 2005, 353:172-87

30. Knebelmann B, Ananth S, Cohen HT, Sukhatme VP: Transforming growth factor alpha is a target for the von Hippel-Lindau tumor suppressor. Cancer Res 1998, 58:226-31.

31. Hudson CC, Liu M, Chiang GG, Otterness DM, Loomis DC, Kaper F, et al: Regulation of hypoxia-inducible factor 1alpha expression and function by the mammalian target of rapamycin. Mol Cell Biol 2002, 22:7004-14.

32. Averous J, Proud CG: When translation meets transformation: the mTOR story. Oncogene 2006, 25:6423-35.

33. Sato T, Nakashima A, Guo L, Coffman K, Tamanoi F: Single amino-acid changes that confer constitutive activation of mTOR are discovered in human cancer. Oncogene 2010, 29:2746-52.

34. Daniel Fl, Cherubini K, Yurgel LS, de Figueiredo MA, Salum FG: The role of epigenetic transcription repression and DNA methyltransferases in cancer. Cancer 2011, 117:677-87.

35. Beyer S, Kristensen MM, Jensen KS, Johansen JV, Staller P: The histone demethylases JMJD1A and JMJD2B are transcriptional targets of hypoxia-inducible factor HIF. J Biol Chem 2008, 283:36542-52.

36. Wellmann S, Bettkober M, Zelmer A, Seeger K, Faigle M, Eltzschig HK, et al: Hypoxia upregulates the histone demethylase JMJD1A via HIF-1. Biochem Biophys Res Commun 2008, 372:892-7

37. Dalgliesh GL, Furge K, Greenman C, Chen L, Bignell G, Butler A, et al Systematic sequencing of renal carcinoma reveals inactivation of histone modifying genes. Nature 2010, 463:360-3.

38. Varela I, Tarpey P, Raine K, Huang D, Ong CK, Stephens P, et al: Exome sequencing identifies frequent mutation of the SWI/SNF complex gene PBRM1 in renal carcinoma. Nature 2011, 469:539-42

39. Delahunt B, Eble JN: Papillary renal cell carcinoma: a clinicopathologic and immunohistochemical study of 105 tumors. Modern Pathol 1997, 10:537-44.

40. Kovacs G, Kovacs A: Parenchymal abnormalities associated with papillary renal cell tumors. J Urol Pathol 1993, 1:301-12.

41. Schmidt L, Duh FM, Chen F, Kishida T, Glenn G, Choyke P, et al: Germline and somatic mutations in the tyrosine kinase domain of the MET protooncogene in papillary renal carcinomas. Nat Genet 1997, 16:68-73.

42. Jeffers M, Schmidt L, Nakaigawa N, Webb CP, Weirich G, Kishida T, et al: Activating mutations for the met tyrosine kinase receptor in human cancer. Proc Natl Acad Sci USA 1997, 94:11445-50.

43. Lubensky IA, Schmidt L, Zhuang Z, Weirich G, Pack S, Zambrano N, et al: Hereditary and sporadic papillary renal carcinomas with c-met mutations share a distinct morphological phenotype. Am J Pathol 1999, 155:517-26.

44. Morris MR, Gentle D, Abdulrahman M, Maina EN, Gupta K, Banks RE, et al: Tumor suppressor activity and epigenetic inactivation of hepatocyte growth factor activator inhibitor type 2/SPINT2 in papillary and clear cell renal cell carcinoma. Cancer Res 2005, 65:4598-606.

45. Toro JR, Nickerson ML, Wei MH, Warren MB, Glenn GM, Turner ML, et al: Mutations in the fumarate hydratase gene cause hereditary leiomyomatosis and renal cell cancer in families in North America. Am J Hum Genet 2003, 73:95-106.
46. Ricketts C, Woodward ER, Killick P, Morris MR, Astuti D, Latif F, et al: Germline SDHB mutations and familial renal cell carcinoma. J Natl Cancer Inst 2008, 100:1260-2.

47. Yan H, Bigner DD, Velculescu V, Parsons DW: Mutant metabolic enzymes are at the origin of gliomas. Cancer Res 2009, 69:9157-9.

48. Isaacs JS, Jung YJ, Mole DR, Lee S, Torres-Cabala C, Chung YL, et al: HIF overexpression correlates with biallelic loss of fumarate hydratase in renal cancer: novel role of fumarate in regulation of HIF stability. Cancer Cell 2005, 8:143-53.

49. Selak MA, Armour SM, MacKenzie ED, Boulahbel H, Watson DG, Mansfield KD, et al: Succinate links TCA cycle dysfunction to oncogenesis by inhibiting HIF-alpha prolyl hydroxylase. Cancer Cell 2005, 7:77-85.

50. Furge KA, Chen J, Koeman J, Swiatek P, Dykema K, Lucin K, et al: Detection of DNA copy number changes and oncogenic signaling abnormalities from gene expression data reveals MYC activation in high-grade papillary renal cell carcinoma. Cancer Res 2007, 67:3171-6.

51. Kovacs A, Kovacs G: Low chromosome number in chromophobe renal cell carcinomas. Gene Chromosome Canc 1992, 4:267-8.

52. Yusenko MV, Zubakov D, Kovacs G: Gene expression profiling of chromophobe renal cell carcinomas and renal oncocytomas by Affymetrix GeneChip using pooled and individual tumours. Int J Biol SCi 2009, 5:517-27.

53. Yamazaki K, Sakamoto M, Ohta T, Kanai Y, Ohki M, Hirohashi S: Overexpression of KIT in chromophobe renal cell carcinoma. Oncogene 2003, 22:847-52.

54. Pan CC, Chen PC, Chiang H: Overexpression of KIT (CD117) in chromophobe renal cell carcinoma and renal oncocytoma. Am J Clin Pathol 2004, 121:878-83.

55. Schoenberg M, Cairns P, Brooks JD, Marshall FF, Epstein JI, Isaacs WB, et al: Frequent loss of chromosome arms $8 p$ and $13 q$ in collecting duct carcinoma (CDC) of the kidney. Gene Chromosome Cancer 1995, 12:76-80.

56. Rakozy C, Schmahl GE, Bogner S, Storkel S: Low-grade tubularmucinous renal neoplasms: morphologic, immunohistochemical, and genetic features. Mod Pathol 2002, 15:1162-71.

57. Ferlicot S, Allory Y, Comperat E, Mege-Lechevalier F, Dimet S, Sibony M, et al: Mucinous tubular and spindle cell carcinoma: a report of 15 cases and a review of the literature. Virchows Arch 2005, 447:978-83.

58. Argani P, Hawkins A, Griffin CA, Goldstein JD, Haas M, Beckwith JB, et al: A distinctive pediatric renal neoplasm characterized by epithelioid morphology, basement membrane production, focal HMB45 immunoreactivity, and $\mathrm{t}(6 ; 11)(\mathrm{p} 21.1 ; \mathrm{q} 12)$ chromosome translocation. Am J Pathol 2001, 158:2089-96.

59. Argani P, Antonescu CR, Couturier J, Fournet JC, Sciot R, Debiec-Rychter M, et al: PRCC-TFE3 renal carcinomas: morphologic, immunohistochemical, ultrastructural, and molecular analysis of an entity associated with the $t$ (X;1)(p11.2;q21). Am J Surg Pathol 2002, 26:1553-66.

60. Martignoni G, Pea M, Gobbo S, Brunelli M, Bonetti F, Segala D, et al: Cathepsin-K immunoreactivity distinguishes MiTF/TFE family renal translocation carcinomas from other renal carcinomas. Modern Pathol 2009, 22:1016-22.

61. Leibovich BC, Lohse CM, Crispen PL, Boorjian SA, Thompson RH, Blute ML, et al: Histological subtype is an independent predictor of outcome for patients with renal cell carcinoma. J Urol 2010, 183:1309-15.

62. Motzer RJ, Bacik J, Mariani T, Russo P, Mazumdar M, Reuter V: Treatment outcome and survival associated with metastatic renal cell carcinoma of non-clear-cell histology. J Clin Oncol 2002, 20:2376-81.

63. de Peralta-Venturina M, Moch H, Amin M, Tamboli P, Hailemariam S, Mihatsch $M$, et al: Sarcomatoid differentiation in renal cell carcinoma: a study of 101 cases. Am J Surg Pathol 2001, 25:275-84.

64. Mekhail TM, Abou-Jawde RM, Boumerhi G, Malhi S, Wood L, Elson P, et al: Validation and extension of the Memorial Sloan-Kettering prognostic factors model for survival in patients with previously untreated metastatic renal cell carcinoma. J Clin Oncol 2005, 23:832-41.

65. Dash A, Carver BS, Stasi J, Bajorin DF, Motzer RJ, Bosl GJ, et al: The indication for postchemotherapy lymph node dissection in clinical stage IS nonseminomatous germ cell tumor. Cancer 2008, 112:800-5.

66. Golshayan AR, George S, Heng DY, Elson P, Wood LS, Mekhail TM, et al: Metastatic sarcomatoid renal cell carcinoma treated with vascular endothelial growth factor-targeted therapy. J Clin Oncol 2009, 27:235-41. 
67. Fisher RA, Pendeer A, Thillai K, Chowdhury S, Pickering LM, Rose SS, et al: Observation prior to systemic therapy in patients with metastatic renal cell carcinoma in the kinase inhibitor era. J Clin Oncol 2011, 29, Abstr 4630.

68. Churchill E, Barney JD: Adenocarcinoma of the kidney with metastasis to the lung: cured by nephrectomy and lobectomy. J Urol 1939, 142:468-73.

69. Russo P: Multi-modal treatment for metastatic renal cancer: the role of surgery. World J Urol 2010, 28:295-301.

70. Alt AL, Boorjian SA, Lohse CM, Costello BA, Leibovich BC, Blute ML: Survival after complete surgical resection of multiple metastases from renal cell carcinoma. Cancer 2011, 117:2873-82.

71. Rini BI, Shaw V, Rosenberg JE, Kim ST, Chen I: Patients with metastatic renal cell carcinoma with long-term disease-free survival after treatment with sunitinib and resection of residual metastases. Clin Genitour Cancer 2006, 5:232-4.

72. Karam JA, Rini BI, Varella L, Garcia JA, Dreicer R, Choueiri TK, et al: Metastasectomy after targeted therapy in patients with advanced renal cell carcinoma. J Urol 2011, 185:439-44.

73. Abrams TJ, Lee LB, Murray LJ, Pryer NK, Cherrington JM: SU11248 inhibits KIT and platelet-derived growth factor receptor beta in preclinical models of human small cell lung cancer. Mol Cancer Ther 2003, 2:471-8.

74. O'Farrell AM, Abrams TJ, Yuen HA, Ngai TJ, Louie SG, Yee KW, et al: SU11248 is a novel FLT3 tyrosine kinase inhibitor with potent activity in vitro and in vivo. Blood 2003, 101:3597-605.

75. Motzer RJ, Hutson TE, Tomczak P, Michaelson MD, Bukowski RM, Rixe O, et al: Sunitinib versus interferon alfa in metastatic renal-cell carcinoma. $N$ Engl J Med 2007, 356:115-24.

76. Gore ME, Szczylik C, Porta C, Bracarda S, Bjarnason GA, Oudard S, et al: Safety and efficacy of sunitinib for metastatic renal-cell carcinoma: an expanded-access trial. Lancet Oncol 2009, 10:757-63.

77. Wilhelm SM, Carter C, Tang L, Wilkie D, McNabola A, Rong H, et al: BAY 439006 exhibits broad spectrum oral antitumor activity and targets the RAF/MEK/ERK pathway and receptor tyrosine kinases involved in tumor progression and angiogenesis. Cancer Res 2004, 64:7099-109.

78. Escudier B, Eisen T, Stadler WM, Szczylik C, Oudard S, Siebels M, et al: Sorafenib in advanced clear-cell renal-cell carcinoma. N Engl J Med 2007, 356:125-34.

79. Castaneda CA, Gomez HL: Pazopanib: an antiangiogenic drug in perspective. Future Oncol 2009, 5:1335-48.

80. Sternberg CN, Davis ID, Mardiak J, Szczylik C, Lee E, Wagstaff J, et al: Pazopanib in locally advanced or metastatic renal cell carcinoma: results of a randomized phase III trial. J Clin Oncol 2010, 28:1061-8.

81. Sternberg CN, Hawkins RE, Szczylik C, Davis ID, Wagstaff J, McCann L, et al: Randomized, double-blind phase III study of pazopanib in patients with advanced/metastatic renal cell carcinoma: final overall survival results. Ann Oncol 2010, 21, Abstr LBA22.

82. Schmelzle T, Hall MN: TOR, a central controller of cell growth. Cell 2000, 103:253-62.

83. Fingar DC, Richardson CJ, Tee AR, Cheatham L, Tsou C, Blenis J: mTOR controls cell cycle progression through its cell growth effectors S6K1 and 4E-BP1/eukaryotic translation initiation factor 4E. Mol Cell Biol 2004, 24:200-16

84. Harding MW: Immunophilins, mTOR, and pharmacodynamic strategies for a targeted cancer therapy. Clin Cancer Res 2003, 9:2882-6.

85. Yu K, Toral-Barza L, Discafani C, Zhang WG, Skotnicki J, Frost P, et al: mTOR, a novel target in breast cancer: the effect of $\mathrm{CCl}-779$, an mTOR inhibitor, in preclinical models of breast cancer. Endocr Relat Cancer 2001, 8:249-58.

86. Thomas GV, Tran C, Mellinghoff IK, Welsbie DS, Chan E, Fueger B, et al: Hypoxia-inducible factor determines sensitivity to inhibitors of mTOR in kidney cancer. Nat Med 2006, 12:122-7.

87. Del Bufalo D, Ciuffreda L, Trisciuoglio D, Desideri M, Cognetti F, Zupi G, et al: Antiangiogenic potential of the Mammalian target of rapamycin inhibitor temsirolimus. Cancer Res 2006, 66:5549-54.

88. Hudes G, Carducci M, Tomczak P, Dutcher J, Figlin R, Kapoor A, et al: Temsirolimus, interferon alfa, or both for advanced renal-cell carcinoma. N Engl J Med 2007, 356:2271-81.

89. Motzer RJ, Escudier B, Oudard S, Hutson TE, Porta C, Bracarda S, et al: Efficacy of everolimus in advanced renal cell carcinoma: a double-blind, randomised, placebo-controlled phase III trial. Lancet 2008, 372:449-56.

90. Yang JC, Haworth L, Sherry RM, Hwu P, Schwartzentruber DJ, Topalian SL, et al: A randomized trial of bevacizumab, an anti-vascular endothelial growth factor antibody, for metastatic renal cancer. N Engl J Med 2003, 349:427-34.

91. Escudier B, Pluzanska A, Koralewski P, Ravaud A, Bracarda S, Szczylik C, et al: Bevacizumab plus interferon alfa-2a for treatment of metastatic renal cell carcinoma: a randomised, double-blind phase III trial. Lancet 2007, 370:2103-11.

92. Rini BI, Halabi S, Rosenberg JE, Stadler WM, Vaena DA, Ou SS, et al: Bevacizumab plus interferon alfa compared with interferon alfa monotherapy in patients with metastatic renal cell carcinoma: CALGB 90206. J Clin Oncol 2008, 26:5422-8.

93. Rini Bl, Vogelzang NJ, Dumas MC, Wade 3rd JL, Taber DA, Stadler WM: Phase II trial of weekly intravenous gemcitabine with continuous infusion fluorouracil in patients with metastatic renal cell cancer. J Clin Oncol 2000, 18:2419-26.

94. Tannir NM, Thall PF, Ng CS, Wang X, Wooten L, Siefker-Radtke A, et al: A phase II trial of gemcitabine plus capecitabine for metastatic renal cell cancer previously treated with immunotherapy and targeted agents. $J$ Urol 2008, 180:867-72.

95. Waters JS, Moss C, Pyle L, James M, Hackett S, A'Hern R, et al: Phase II clinical trial of capecitabine and gemcitabine chemotherapy in patients with metastatic renal carcinoma. Br J Cancer 2004, 91:1763-8.

96. Stadler WM, Halabi S, Rini B, Ernstoff MS, Davila E, Picus J, et al: A phase II study of gemcitabine and capecitabine in metastatic renal cancer: a report of Cancer and Leukemia Group B protocol 90008. Cancer 2006, 107:1273-9.

97. Richey SL, Ng C, Lim ZD, Jonasch E, Tannir NM: Durable remission of metastatic renal cell carcinoma with gemcitabine and capecitabine after failure of targeted therapy. J Clin Oncol 2011, 29:e203-5.

98. Brahmer JR, Drake CG, Wollner I, Powderly JD, Picus J, Sharfman WH, et al: Phase I study of single-agent anti-programmed death-1 (MDX-1106) in refractory solid tumors: safety, clinical activity, pharmacodynamics, and immunologic correlates. J Clin Oncol 2010, 28:3167-75.

99. Hirano F, Kaneko K, Tamura H, Dong H, Wang S, Ichikawa M, et al: Blockade of B7-H1 and PD-1 by monoclonal antibodies potentiates cancer therapeutic immunity. Cancer Res 2005, 65:1089-96.

100. Dong H, Strome SE, Salomao DR, Tamura H, Hirano F, Flies DB, et al: Tumor-associated $\mathrm{B} 7-\mathrm{H} 1$ promotes T-cell apoptosis: a potential mechanism of immune evasion. Nat Med 2002, 8:793-800.

101. Thompson RH, Kuntz SM, Leibovich BC, Dong H, Lohse CM, Webster WS, et al: Tumor $\mathrm{B} 7-\mathrm{H} 1$ is associated with poor prognosis in renal cell carcinoma patients with long-term follow-up. Cancer Res 2006, 66:3381-5.

102. Stadler WM, Figlin RA, McDermott DF, Dutcher JP, Knox JJ, Miller WH Jr, et al: Safety and efficacy results of the advanced renal cell carcinoma sorafenib expanded access program in North America. Cancer 2010, 116:1272-80.

103. Choueiri TK, Plantade A, Elson P, Negrier S, Ravaud A, Oudard S, et al: Efficacy of sunitinib and sorafenib in metastatic papillary and chromophobe renal cell carcinoma. J Clin Oncol 2008, 26:127-31.

104. Hudes GR, Berkenblit A, Feingold J, Atkins MB, Rini BI, Dutcher J: Clinical trial experience with temsirolimus in patients with advanced renal cell carcinoma. Semin Oncol 2009, 36(Suppl 3):S26-36.

105. Dutcher JP, de Souza P, McDermott D, Figlin RA, Berkenblit A, Thiele A, et al: Effect of temsirolimus versus interferon-alpha on outcome of patients with advanced renal cell carcinoma of different tumor histologies. Med Oncol 2009, 26:202-9.

106. Plimack ER, Jonasch E, Bekele BN, Qiao W, Ng CS, Tannir NM: Sunitinib in papillary renal cell carcinoma: Results from a single-arm phase II study. $J$ Clin Oncol 2010, 28, Abstr 4604.

107. Vickers MM, Heng DY: Prognostic and predictive biomarkers in renal cell carcinoma. Target Oncol 2010, 5:85-94.

108. Huang D, Ding Y, Li Y, Luo WM, Zhang ZF, Snider J, et al: Sunitinib acts primarily on tumor endothelium rather than tumor cells to inhibit the growth of renal cell carcinoma. Cancer Res 2010, 70:1053-62.

109. Signoretti S, Bratslavsky G, Waldman FM, Reuter VE, Haaga J, Merino M, et al: Tissue-based research in kidney cancer: current challenges and future directions. Clin Cancer Res 2008, 14:3699-705.

110. Choueiri TK, Vaziri SA, Jaeger E, Elson P, Wood L, Bhalla IP, et al: von Hippel-Lindau gene status and response to vascular endothelial growth factor targeted therapy for metastatic clear cell renal cell carcinoma. $J$ Urol 2008, 860:5 
111. Gad S, Sultan-Amar V, Meric JB, Izzedine H, Khayat D, et al: Somatic von Hippel-Lindau (VHL) gene analysis and clinical outcome under antiangiogenic treatmetn in metastatic renal cell carcinoma: preliminary results. Targ Oncol 2007, 2:3-6.

112. Hutson TE, Davis ID, Macheils JH, de Souza PL, Baker K, Bordogna W, et al: Biomarker analysis and final efficacy and safety results of a phase II renal cell carcinoma trial with pazopanib (GW786034), a multikinase angiogenesis inhibitor. J Clin Oncol 2008, 26, Abstr 5046.

113. Carroll VA, Ashcroft M: Role of hypoxia-inducible factor (HIF)-1alpha versus HIF-2alpha in the regulation of HIF target genes in response to hypoxia, insulin-like growth factor-I, or loss of von Hippel-Lindau function: implications for targeting the HIF pathway. Cancer Res 2006, 66:6264-70.

114. Gordan JD, Lal P, Dondeti VR, Letrero R, Parekh KN, Oquendo CE, et al: HIFalpha effects on c-Myc distinguish two subtypes of sporadic VHLdeficient clear cell renal carcinoma. Cancer Cell 2008, 14:435-46.

115. Lidgren A, Hedberg Y, Grankvist K, Rasmuson T, Vasko J, Ljungberg B: The expression of hypoxia-inducible factor 1alpha is a favorable independent prognostic factor in renal cell carcinoma. Clin Cancer Res 2005, 11:1129-35.

116. Lidgren A, Hedberg Y, Grankvist K, Rasmuson T, Bergh A, Ljungberg B: Hypoxia-inducible factor 1alpha expression in renal cell carcinoma analyzed by tissue microarray. Eur Urol 2006, 50:1272-7.

117. Klatte T, Seligson DB, Riggs SB, Leppert JT, Berkman MK, Kleid MD, et al: Hypoxia-inducible factor 1 alpha in clear cell renal cell carcinoma. Clin Cancer Res 2007, 13:7388-93.

118. Dorevic G, Matusan-Ilijas K, Babarovic E, Hadzisejdic I, Grahovac M, Grahovac B, et al: Hypoxia inducible factor-1alpha correlates with vascular endothelial growth factor $\mathrm{A}$ and $\mathrm{C}$ indicating worse prognosis in clear cell renal cell carcinoma. J Exp Clin Cancer Res 2009, 28:40.

119. Patel PH, Chadalavada RS, Ishill NM, Patil S, Reuter VE, Motzer RJ, et al: Hypoxia-inducible factor (HIF) $1 a$ and $2 a$ levels in cell lines and human tumor predicts response to sunitinib in renal cell carcinoma (RCC). J Clin Oncol 2008, 26, Abstract 5008.

120. Pena C, Lathia C, Shan M, Escudier B, Bukowski RM: Biomarkers predicting outcome in patients with advanced renal cell carcinoma: results from sorafenib phase III Treatment Approaches in Renal Cancer Global Evaluation Trial. Clin Cancer Res 2010, 16:4853-63.

121. Negrier S, Chabaud S, Escudier B, Ravaud A, Chevreau C, Blay JY, et al: Serum level of vascular endothelial growth factor (VEGF) as an independent prognostic factor in metastatic renal cell carcinoma (MRCC). J Clin Oncol 2007, 25, Abstract 5044.

122. Escudier BJ, Ravaud A, Négrier S, Szczylik C, Bellmunt Molins J, Bracarda S, et al: Update on AVOREN trial in metastatic renal cell carcinoma: Efficacy and safety in subgroups of patients and pharmacokinetic analysis. J Clin Oncol 2008, 26, Abstr 5025.

123. Rini BI, Michaelson MD, Rosenberg JE, Bukowski RM, Sosman JA Stadler WM, et al: Antitumor activity and biomarker analysis of sunitinib in patients with bevacizumab-refractory metastatic renal cell carcinoma. J Clin Oncol 2008, 26:3743-8.

124. Deprimo SE, Bello CL, Smeraglia J, Baum CM, Spinella D, Rini Bl, et al: Circulating protein biomarkers of pharmacodynamic activity of sunitinib in patients with metastatic renal cell carcinoma: modulation of VEGF and VEGF-related proteins. J Trans/ Med 2007, 5:32.

125. Bui MH, Seligson D, Han KR, Pantuck AJ, Dorey FJ, Huang Y, et al: Carbonic anhydrase IX is an independent predictor of survival in advanced renal clear cell carcinoma: implications for prognosis and therapy. Clin Cancer Res 2003, 9:802-11.

126. Sandlund J, Oosterwijk E, Grankvist K, Oosterwijk-Wakka J, Ljungberg B, Rasmuson T: Prognostic impact of carbonic anhydrase IX expression in human renal cell carcinoma. BJU Int 2007, 100:556-60.

127. Leibovich BC, Sheinin Y, Lohse CM, Thompson RH, Cheville JC, Zavada J, et al: Carbonic anhydrase IX is not an independent predictor of outcome for patients with clear cell renal cell carcinoma. J Clin Oncol 2007, 25:4757-64.

128. Atkins M, Regan M, McDermott D, Mier J, Stanbridge E, Youmans A, et al: Carbonic anhydrase IX expression predicts outcome of interleukin 2 therapy for renal cancer. Clin Cancer Res 2005, 11:3714-21.

129. Pantuck AJ, Fang Z, Lui X, Seligson DB, Horvath S, Leppert JT, et al: Gene expression and tissue microarray analysis of interleukin-2 complete responders in patients with metastatic renal cell carcinoma. J Clin Oncol 2005, 23, Abstr 4535.
130. Cho D, Signoretti S, Dabora S, Regan M, Seeley A, Mariotti M, et al: Potential histologic and molecular predictors of response to temsirolimus in patients with advanced renal cell carcinoma. Clin Genitour Cancer 2007, 5:379-85.

131. Devarajan P: The promise of biomarkers for personalized renal cancer care. Kidney Int 2010, 77:755-7.

132. Haase M, Bellomo R, Devarajan P, Schlattmann P, Haase-Fielitz A: Accuracy of neutrophil gelatinase-associated lipocalin (NGAL) in diagnosis and prognosis in acute kidney injury: a systematic review and meta-analysis. Am J Kidney Dis 2009, 54:1012-24.

133. Mitsnefes MM, Kathman TS, Mishra J, Kartal J, Khoury PR, Nickolas TL, et al: Serum neutrophil gelatinase-associated lipocalin as a marker of renal function in children with chronic kidney disease. Pediatr Nephrol 2007 22:101-8.

134. Devarajan P: Neutrophil gelatinase-associated lipocalin: new paths for an old shuttle. Cancer Ther 2007, 5:463-70.

135. Porta C, Paglino C, De Amici M, Quaglini S, Sacchi L, Imarisio I, et al: Predictive value of baseline serum vascular endothelial growth factor and neutrophil gelatinase-associated lipocalin in advanced kidney cancer patients receiving sunitinib. Kidney Int 2010, 77:809-15.

136. Hutterer GC, Patard JJ, Colombel M, Belldegrun AS, Pfister C, Guille F, et al: Cytoreductive nephron-sparing surgery does not appear to undermine disease-specific survival in patients with metastatic renal cell carcinoma. Cancer 2007, 110:2428-33.

137. Abou Youssif T, Fahmy MA, Koumakpayi IH, Ayala F, Al Marzooqi S, Chen G, et al: The mammalian target of rapamycin pathway is widely activated without PTEN deletion in renal cell carcinoma metastases. Cancer 2011, 117:290-300

138. Figlin RA, de Souza P, McDermott D, Dutcher JP, Berkenblit A, Thiele A, et al: Analysis of PTEN and HIF-1alpha and correlation with efficacy in patients with advanced renal cell carcinoma treated with temsirolimus versus interferon-alpha. Cancer 2009, 115:3651-60.

139. George D, Armstrong AJ, Halabi S: Serum lactate dehydrogenase (LDH) as a biomarker for survival with mTOR inhibition in patients with metastatic renal cell carcinoma. J Clin Oncol 2010, 28, Abstr 4631.

140. Klatte T, Rao PN, de Martino M, LaRochelle J, Shuch B, Zomorodian N, et al: Cytogenetic profile predicts prognosis of patients with clear cell renal cell carcinoma. J Clin Oncol 2009, 27:746-53.

141. Brannon AR, Reddy A, Seiler M, Arreola A, Moore DT, Pruthi RS, et al: Molecular stratification of clear cell renal cell carcinoma by consensus clustering reveals distinct subtypes and survival patterns. Gene Cancer 2010, 1:152-63.

142. Rini Bl, Zhou M, Aydin H, Elson P, Maddala T, Knezevic D, et al: Identification of prognostic genomic markers in patients with localised clear cell renal carcinoma. J Clin Oncol 2010, 28, Abstr 4501.

143. Kleinrath T, Gassner C, Lackner P, Thurnher M, Ramoner R: Interleukin-4 promoter polymorphisms: a genetic prognostic factor for survival in metastatic renal cell carcinoma. J Clin Oncol 2007, 25:845-51.

144. Kawai Y, Sakano S, Korenaga Y, Eguchi S, Naito K: Associations of single nucleotide polymorphisms in the vascular endothelial growth factor gene with the characteristics and prognosis of renal cell carcinomas. Eur Urol 2007, 52:1147-55.

145. Xu CF, Bing NX, Ball HA, Rajagopalan D, Sternberg CN, Hutson TE, et al: Pazopanib efficacy in renal cell carcinoma: evidence for predictive genetic markers in angiogenesis-related and exposure-related genes. J Clin Oncol 2011, 29:2557-64.

146. Rini BI, Cohen DP, Lu DR, Chen I, Hariharan S, Gore ME, et al: Hypertension as a biomarker of efficacy in patients with metastatic renal cell carcinoma treated with sunitinib. J Natl Cancer Inst 2011, 103:763-73.

147. Rini BI, Schiller JH, Fruehauf JP, Cohen EE, Tarazi JC, Rosbrook B, et al: Association of diastolic blood pressure $>=90 \mathrm{mmHg}$ with overall survival in patients treated with axitinib (AG-013736). J Clin Oncol 2008, 26, Abstr 3543.

148. Bono $P$, Elfving $H$, Utriainen $T$, Osterlund $P$, Saarto $T$, Alanko $T$, et al: Hypertension and clinical benefit of bevacizumab in the treatment of advanced renal cell carcinoma. Ann Oncol 2009, 20:393-4.

149. Rixe O, Dutcher J, Motzer R, Wilding G, Stadler WM, Garrett M, et al: Diastolic blood pressure and pharmacokinetics as predictors of axitinib efficacy in metastatic renal cell cancer. J Clin Oncol 2009, 27, Abstr 5045.

150. Kim JJ, Vaziri SA, Elson P, Rini BI, Patel A, Basappa NS, et al: VEGF single nucleotide polymorphisms (SNPs) and correlation to baseline and 
sunitinib-induced hypertension in patients with metastatic renal cell carcinoma. ASCO Genitourinary Cancers Symposium 2010, Abstr 330.

151. de Bazelaire C, Alsop DC, George D, Pedrosa I, Wang Y, Michaelson MD, et al: Magnetic resonance imaging-measured blood flow change after antiangiogenic therapy with PTK787/ZK 222584 correlates with clinical outcome in metastatic renal cell carcinoma. Clin Cancer Res 2008, 14:5548-54.

152. Hahn OM, Yang C, Medved M, Karczmar G, Kistner E, Karrison T, et al: Dynamic contrast-enhanced magnetic resonance imaging pharmacodynamic biomarker study of sorafenib in metastatic renal carcinoma. J Clin Oncol 2008, 26:4572-8.

153. Swanton C, Larkin JM, Gerlinger M, Eklund AC, Howell M, Stamp G, et al: Predictive biomarker discovery through the parallel integration of clinical trial and functional genomics datasets. Genome Med 2010, 2:53.

154. Bergers G, Hanahan D: Modes of resistance to anti-angiogenic therapy. Nat Rev Cancer 2008, 8:592-603.

155. Swanton C, Larkin JM, Gerlinger M, Eklund AC, Howell M, Stamp G, et al: Predictive biomarker discovery through the parallel integration of clinical trial and functional genomics datasets. Genome Med 2010, 2:53.

156. Lee AJ, Endesfelder D, Rowan AJ, Walther A, Birkbak NJ, Futreal PA, et al: Chromosomal instability confers intrinsic multidrug resistance. Cancer Res 2011, 71:1858-70.

157. Moch H, Schraml P, Bubendorf L, Richter J, Gasser TC, Mihatsch MJ, et al: Intratumoral heterogeneity of von Hippel-Lindau gene deletions in renal cell carcinoma detected by fluorescence in situ hybridization. Cancer Res 1998, 58:2304-9.

158. Gerlinger M, Swanton C: How Darwinian models inform therapeutic failure initiated by clonal heterogeneity in cancer medicine. Br J Cancer 2010, 103:1139-43

159. Lee AJ, Endesfelder D, Rowan AJ, Walther A, Birkbak NJ, Futreal PA, et al: Chromosomal instability confers intrinsic multidrug resistance. Cancer Res 2011, 71:1858-70.

doi:10.1007/s13167-011-0137-3

Cite this article as: Fisher et al:: Delivering preventive, predictive and personalised cancer medicine for renal cell carcinoma: the challenge of tumour heterogeneity. The EPMA Journal 2012 3:1.

\section{Submit your next manuscript to BioMed Central and take full advantage of:}

- Convenient online submission

- Thorough peer review

- No space constraints or color figure charges

- Immediate publication on acceptance

- Inclusion in PubMed, CAS, Scopus and Google Scholar

- Research which is freely available for redistribution

Submit your manuscript at www.biomedcentral.com/submit 